\title{
ANALYSIS OF THE BANKING SECTOR PERFORMANCE IN BOSNIA AND HERZEGOVINA, MONTENEGRO AND SERBIA BEFORE AND AFTER THE GLOBAL FINANCIAL CRISIS
}

\author{
Antonija Bošnjak, Abeer Hassan, Kieran James \\ University of the West of Scotland, Paisley, Scotland
}

date of paper receipt:

23.11.2017.

Review paper date of sending to review:

04.12.2017.

doi:

10.1515/eoik-2017-0029 date of review receipt:

08.12.2017.

UDK: 339.9:338.124.4

$(497.11+497.6+497.16)$

\section{SUMMARY}

The focus of this study is the banking sector of the three neighbouring countries Bosnia and Herzegovina; Montenegro; and Serbia. These are former communist countries which have been going through the transition from centrally-planned economies to open market economies over the past 25 years. During the transition process, structural reforms were conducted to transform the banking sector into a sector suitable for open market economy. These reforms are considered to be the most successful ones in the region. Before the Global Financial Crisis of 2008-09, the economies of the three selected countries were experiencing credit booms. The aim of this research was to examine how the banking sector is performing on an aggregated level years after the crisis and whether the performance is better or worse compared to the pre-crisis period. The findings show that the banking sector was performing better before the crisis in all three countries. After the crisis, the three countries experienced prolonged slow credit growth and had higher nonperforming loans.

Keywords: Banking sector; Bosnia and Herzegovina; Global Financial Crisis; Montenegro; Nonperforming loans; Post-communism; Serbia.

\section{INTRODUCTION}

\section{GENERAL INTRODUCTION}

The topic of this research study is banking sector development in three neighbouring countries in South-eastern Europe namely Bosnia and Herzegovina; Montenegro; and Serbia. As with other former planned economies, these three countries had to undergo a transition process to be transformed into open-market capitalist economies. Part of that process involved transformation of the banking sectors.

Structural reforms, as part of the transition process, have attempted to transform the banking systems of former communist countries into modern banking systems suitable for open-market economies. Domestic state-owned banks were mostly privatized by foreign private-capital or were closed due to undercapitalization. New regulatory frameworks were introduced and bank supervision enhanced. These changes generally had positive effects on public trust in the banking 
systems. Before the Global Financial Crisis (hereafter GFC) of 2008-09 was felt, credit activity was intense and the profitability of the banking sectors in all three countries was satisfactory or better. However, the GFC changed the environment and conditions under which the banks operate. In 2009, the negative effects of the GFC spilt over into these three countries causing recession. Since the banking systems were not directly exposed to 'toxic assets', the GFC was transmitted to the region indirectly. The effects of these indirect transmissions included a contraction of international trade; a sudden cessation of credit growth; a fall in inflow of foreign direct investment; and a fall in remittances from migrant workers. These reflected the impact of the GFC on financial markets; goods markets; capital markets; and labour markets (Bartlett and Monastiriotis, 2010).

The aim of this research was to investigate whether the banking sectors of the three selected countries are performing better now as compared to the pre-GFC period.

\section{RESEARCH QUESTION}

The authors' goal was to investigate the conditions of and changes to the banking sectors in the 2008-16 period in South-eastern Europe by analysing data for the three countries mentioned previously: Bosnia and Herzegovina; Montenegro; and Serbia. The aim was to examine the latest available data related to the banking sector; compare it to the pre-GFC period; and answer the main research question which is as follows:

Research Question 1: Have the banking sectors in Bosnia and Herzegovina, Montenegro and Serbia recovered from the Global Financial Crisis (GFC) of 2008-09 and do they currently perform better? To be able to adequately answer this question, the following areas had to be researched and analysed: the intensity of credit activity; the sources of funding of the banking sector; the quality of credit portfolio; the intensity of deposit activity; and profitability of the banking sector. Credit and deposit activity had to be analysed because they are core business areas of commercial banks (Van Horne and Wachowicz, 2008).

\section{RESEARCH METHOD AND LIMITATIONS}

Due to the nature of the research question, the authors' only possible option was quantitative analysis of numerical data collected from secondary sources (e.g. monetary authorities of the selected countries; the World Bank; and the International Monetary Fund). Variables compared preGFC and post-GFC period were: level of credit activity compared to gross domestic products and total bank assets; trends of total loans and sectoral structure of loans (household sector and sector of non-financial corporations) measured as annual growth rates and shares in total; total assets compared to GDP and to total assets of financial systems; quality of assets and credit portfolios measured as share of non-performing loans in total credit portfolios; ownership structures of banking sector capital and numbers of banks; deposit activity and sectoral structures of deposits measured as annual growth rates and shares in total sources of funding of bank activities; shares of non-performing loans; returns on assets (hereafter ROA); and returns on equity (ROE).

The data was collected from the central bank statistical database websites of each of the selected countries; the International Monetary Fund (IMF); the World Bank; and the United Nations (UN). In addition, data from different reports and publications by the above-mentioned institutions were utilized, as well as information obtained from banking supervisory agencies.

The authors were faced with the challenging issue of limited availability of data for the analysed countries, which impeded the full review of longer time series and comparative analysis of the banking sectors in the selected countries. Most publicly-available data for the banking sectors of Bosnia and Herzegovina and Serbia refer to periods beginning from 2000 and 2002, respectively, until 2016, which is the most recent year observed for this study. However, most data for the banking sector of Montenegro is only available from 2006 onwards. 


\section{STRUCTURE}

The present article is organised into the following four sections. The first section (presented above) introduced the topic; the research question; and the research method. The second section presents a review of prior literature and is divided into two sub-sections. The first sub-section gives a brief overview of the importance of the financial sector and the roles of banks; while the second subsection discusses banking sector developments specific to the former centrally-planned selected countries, as well as the influence of the GFC on the banking sectors. The results and discussion are presented in Section 3; whilst Section 4 concludes.

\section{LITERATURE REVIEW}

Importance of a functional financial system and the role of banks

Before introducing banking sector development in Bosnia and Herzegovina; Montenegro; and Serbia, a brief overview of the importance of a functional and stable financial sector is provided, and the main roles of banks are explored.

The financial sector is a complex industry comprised of financial institutions, markets, and instruments, whose main purpose is to efficiently allocate funds to those projects which will yield the highest rate of return for a given risk. The main function of financial system intermediation is to utilize the advantage of economies of scale, i.e. pooling funds together from various lenders (investors, savers) and transferring them to borrowers; this, in turn, lowers transaction costs compared to direct financing, and reduces the exposure of lenders to risk because their investments will be dispersed across various borrowers (Mishkin, 2012). Much of the risk is diversifiable (idiosyncratic).

As Karl Marx might have pointed out, the functionality of the financial system of a country is determined by the economic development of that country. However, the financial system itself also has a significant (reverse) impact on economic growth. A number of studies document a strong positive correlation between a functioning financial system and economic growth (Eschenbach, 2004; Levine, 2005). Duisenberg (2001) emphasizes the important role that financial intermediaries play in overcoming the problems of adverse selection and moral hazard that exist between lenders and borrowers, and they ensure that funds are reallocated to the most promising projects.

Owing to its vital role in efficiently allocating funds and supporting economic growth, stability of the financial system is of utmost importance, a fact brought to the forefront of people's consciousness following the GFC of 2008-09. Schinasi (2004, p. 10) defines financial stability as a condition under which an economy's mechanisms for pricing, allocation, and management of financial risks are functioning well enough to contribute to the performance of the economy. The World Bank definition is more specific regarding performance of the economy, and states that: 'a stable financial system is made of financial intermediaries, markets and market infrastructure, is capable of efficiently allocating resources, assessing and managing financial risks, maintaining employment levels close to the economy's natural rate, and eliminating relative price movements of real or financial assets that will affect monetary stability or employment levels' (Financial Stability, $\mathrm{n} / \mathrm{d}$ ). Most modern definitions of financial system stability focus on the financial system as a whole operating as it does as part of the real economy (Borio and Drehmann, 2009). The GFC started in the U.S.A. and then affected the world economy. It was a result of the failure of financial markets to fulfil their purposes especially the failure to prevent adverse selection and moral hazard (Mishkin, 2004).

The main purpose of banks is to provide deposit and loan services to other financial and nonfinancial companies; the government; households; and other economic entities. By providing deposit services, banks allow the liquidity of savings from lenders to be channelled to borrowers for their consumption or business investment needs in the form of loans. By providing fundamental 
deposit-loans services, banks participate in a process called multiple deposit creation which affects the money supply (Mishkin, 2004). When commercial banks lend money to a client, they do not provide it in the form of cash, but rather they credit it to the customer's account, and thus create deposit money (McLeay et al., 2014).

\section{TRANSITION AND BANKING SECTOR REFORM PRIOR TO GLOBAL FINANCIAL CRISIS}

A transition process refers to structural changes which transform a centrally planned economy to a market economy, a process which started at the end of the eighties and the beginning of the nineties of the last century in those countries which abandoned communism. The transition process included: liberalization of prices, trade, and foreign exchange through legal and regulatory changes; privatization of small businesses and large-scale privatization; competition policy; governance reform; and enterprise restructuring (Roaf et al., 2014).

The banking sector of most countries in South-eastern Europe had to undergo major structural reforms during the decades surrounding the turn of the 21st-century. Under communist rule, central banks were functioning as commercial and central banks, a form of banking known as a mono-banking system. The role of banks in centrally-planned economies was administrative / bureaucratic, i.e. the banks were vehicles to carry out government plans and decisions regarding capital allocation to different businesses and sectors (Živko and Kandžija, 2013). The mono-banking system was abandoned after the collapse of the communist regimes in Eastern Europe and the twotier banking system was adopted, meaning separation of the functions of central banks (monetary authorities) from those of commercial banks (or any other type of bank).

Barisitz (2009) recognizes two waves of banking system reform in the move towards a marketoriented system that most of the former communist countries underwent: (a) an initial wave mainly focused on liberalization of the banking market regulations, which allowed undercapitalized private banks to enter the market and led to further deterioration of banking sector assets and destabilization; and (b) a second wave mostly focused on restructuring and institutionalization, which included stricter regulation; privatization of banks by large foreign-owned companies; and accelerated credit activity.

The results of the banking sector reforms may be summarized as follows (Živko and Kandžija, 2013): (a) entry of foreign capital into the banking system; (b) growth in domestic lending, in particular to the household sector; (c) increase in the exposure to foreign currency risk; (d) increase in profitability and a satisfying rate of capital adequacy; (e) credit expansion and growth of risk assets; (f) improvement of the supervisory framework; and (g) implementation of International Accounting Standards Board (IASB) or other high-quality accounting standards.

Although Živko and Kandžija (2013) carried out their analysis of the banking sector in Croatia, most of these results were also achieved in neighbouring countries (Montenegro; Serbia; and Bosnia and Herzegovina) that followed the same path.

Entry of foreign capital into the banking system led to better credit supply and higher quality bank services; improved management of banks; greater satisfaction of clients; entry of new business technologies; improvement of financial system infrastructure; advancement in the competitive environment; and attraction of foreign direct investments (Bajraktarović, 2009; Mešić, 2006).

The transition process and transformation of the banking sectors was mostly completed before the GFC in our three selected countries. Bosnia and Herzegovina, Montenegro, and Serbia modernized their banking systems to comprise commercial (mostly privately-owned) banks, whose business and performance are subject to supervision of independent institutions. These national banking systems were established with the European Union (hereafter EU) as a role model (Bajraktarović, 2009). 
Monetary and banking supervisory authorities in selected countries

In Bosnia and Herzegovina, the banking sector is overseen by two regulatory bodies, namely the Federal Banking Agency of Bosnia and Herzegovina and the Banking Agency of Republic Srpska ${ }^{1}$. The Central Bank of Bosnia and Herzegovina is responsible for monetary policy and for the support and maintenance of appropriate payment and settlement systems; it also co-ordinates the activities of the two supervisory agencies (General Information about the Bank, n/d).

In Montenegro and Serbia, central banks are responsible for both monetary policy and supervision of banks. Nevertheless, regardless of which public body(ies) is / are responsible for banks' supervision, these responsibilities include: bank licensing and revoking bank licences; control of bank performance; enactment of laws and bylaws regarding the banking sector; and generation and dissemination of banking statistics.

\section{IMPACT OF GLOBAL FINANCIAL CRISIS ON BANKING SECTOR IN SELECTED COUNTRIES}

Barjaktarovic et al. (2013), in their study of the impact of the GFC on the development of the banking sector in Central-eastern Europe, analyse in great detail the countries of South-eastern Europe. They conclude that there was an upward trend in the share of loans and deposits in GDP in 2009 and that the banking sector managed to adequately respond to the negative effects of the GFC by implementing more conservative credit policies; improving the classification of clients; increasing the level of equity; and maintaining and planning liquidity positions.

Cocozza et al. (2011), in their work analysing the GFC's impact on South-eastern Europe, which includes six countries from the region, claim that the main feature of the GFC in the region was the absence of a large-scale banking crisis thanks to high capital and liquidity buffers that were the result of supervisory actions taken by central banks. Živković (2011) shares the opinion that the banking sector in South-eastern Europe remained stable, liquid, and relatively profitable thanks to adequate levels of capital and effective measures taken by monetary authorities. However, it is not clear what is meant by the phrase 'relatively profitable banking sector'.

Roaf et al. (2014) consider the main issue during and after the GFC to have been the slow credit growth resulting from the rise of non-performing loans and the deleveraging process. Furthermore, they emphasize their opinion that governments should take a more proactive role in finding solutions for resolution of bad credits. Nurboja and Košak (2017) find that banking efficiency in South-eastern Europe actually improved over the period 2008-2013 with regard to costs, which was probably the result of pressures imposed on banks' managements.

Sanfey (2010) argues that the impact has been better than expected and that this resilience can be attributed to a great extent to the mature and sensible reaction of the region itself and to the financial support of international financial institutions. Whilst the second part of Sanfey's (2010) claim seems credible enough, the first part, regarding the mature and sensible reaction of the region, is debateable.

In conclusion, researchers appear to agree that the GFC did not have an overwhelmingly negative impact on the banking sectors or the financial stability of the region. However, the effect of the GFC may have been underestimated due to comparisons being made with the U.S.A.

Having reviewed the literature related to the banking sector in general and the three selected

$1 \quad$ Not to be confused with Republic Serbia. Republic Serbia is an independent sovereign country. Republic of Srpska is a part of Bosnia and Herzegovina. Administrative division of Bosnia and Herzegovina is quite complex. The country is comprised of two autonomous entities, Federation of Bosnia and Herzegovina and Republic of Srpska and each has its own government and governmental bodies. The central state government has limited power over institutions. While the monetary policy is conducted on the state level, financial supervision is conducted on the entity level. Although two banking agencies exist in Bosnia and Herzegovina, their responsibilities, laws, and regulations are harmonized. 
countries in particular, the authors are not aware of any study that covers longer time series of indicators of banking sector conditions following the GFC and specifically focused on our three countries. Therefore, this research study will try to fill this research gap.

\section{RESULTS AND DISCUSSION}

\section{BANKING SECTOR SOURCES OF FINANCING}

Banks in the discussed countries were mostly privatized by foreign banking groups coming mainly from EU countries. Foreign banks were attracted to the region as the high returns provided them with an opportunity for gain in these transitioning economies (Bartlett and Prica, 2012). Banks could meet demand owing to stable financing from parent banks from abroad. As a result, foreign liabilities were quite an important source of funding for banks in Bosnia and Herzegovina, and Montenegro, and to a much lesser extent for Serbian banks. This was a cheap form of financing for foreign-owned banks that dominate banking markets in the region. Similarly to emerging markets of Central-eastern Europe, which did not engage in wholesale markets to access funds, banks in South-eastern Europe did not do this either (Wiesiołek and Tymoczko, 2015).

\section{FOREIGN LIABILITIES}

Foreign liabilities of the banking sector in Bosnia and Herzegovina made up 28.9\% of total sources of funding in 2008, which was close to the five-year average. In Montenegro that share was even higher, comprising 38.0\% of total sources of funding. On the other hand, Serbian banks seemed to be less dependent on foreign funding, at least in 2008, when foreign liabilities made up 19.0\%. During 2003-2008, foreign liabilities recorded a two-digit growth rate $y / y$ in all three countries, showing how intensive the financing from foreign parent companies was. Bartlett and Prica (2012) find that capital inflows to the region were significant and mainly related to rise in capital and liabilities of foreign-owned banks which entered into the regional market during restructuring and reforming of the banking sector. The results of the present study confirm that liabilities of foreign owned banks had an accelerated increasing trend before the GFC.

However, in the years following the GFC, the trend of foreign liabilities as a source of financing changed completely. From 2009 onwards, the banking sector of Bosnia and Herzegovina has been recording negative annual growth of foreign liabilities, meaning that banks are not taking new loans and deposits from abroad, but rather deleveraging. This can also be confirmed by observing the share of foreign liabilities in total sources of financing, which has seen a constant decreasing trend since 2008. For Serbia, a similar conclusion can be reached. Following 2009, a slowdown began and in 2011 the annual growth turned to negative and stayed negative until the end of the observed period, with the exception of 2012. Only the banking sector of Montenegro has recorded growth in the last two years, but the share of foreign financing is much lower than it was in 2008.

\section{CAPITAL}

From 2009 onwards, the share of capital as a source of financing seems to be more stable than the share of foreign liabilities. Before the recession, capital financing showed a decreasing trend in Bosnia and Herzegovina, and Montenegro, while in Serbia it displayed a more volatile trend. However, following the GFC, there have been no major changes in the share of capital in total sources of financing, proving that foreign owned banks had support from parent companies. 
Table 1 Share of foreign liabilities in total sources of funding and annual growth rates of stocks of foreign liabilities

\begin{tabular}{|c|c|c|c|c|c|c|}
\hline \multirow[t]{2}{*}{ Year } & \multicolumn{2}{|c|}{ Bosnia and Herzegovina } & \multicolumn{2}{|l|}{ Serbia } & \multicolumn{2}{|l|}{ Montenegro } \\
\hline & $\begin{array}{l}\text { Share in } \\
\text { total }\end{array}$ & $\begin{array}{l}\text { Growth } \\
\text { rate }\end{array}$ & $\begin{array}{l}\text { Share in } \\
\text { total }\end{array}$ & $\begin{array}{l}\text { Growth } \\
\text { rate }\end{array}$ & $\begin{array}{l}\text { Share in } \\
\text { total }\end{array}$ & $\begin{array}{l}\text { Growth } \\
\text { rate }\end{array}$ \\
\hline $\begin{array}{l}2003-2008 \text { aver- } \\
\text { age }\end{array}$ & $28.3 \%$ & $28.3 \%$ & $23.4 \%$ & $37.3 \%$ & $22.5 \%$ & $100.8 \%$ \\
\hline 2008 & $28.9 \%$ & $24.5 \%$ & $19.0 \%$ & $15.9 \%$ & $38.0 \%$ & $57.4 \%$ \\
\hline 2009 & $26.1 \%$ & $-10.2 \%$ & $26.3 \%$ & $69.0 \%$ & $34.4 \%$ & $-17.3 \%$ \\
\hline 2010 & $21.2 \%$ & $-18.4 \%$ & $28.5 \%$ & $27.0 \%$ & $31.6 \%$ & $-10.4 \%$ \\
\hline 2011 & $17.6 \%$ & $-14.0 \%$ & $25.0 \%$ & $-6.9 \%$ & $28.6 \%$ & $-13.7 \%$ \\
\hline 2012 & $16.2 \%$ & $-5.8 \%$ & $23.6 \%$ & $2.8 \%$ & $24.9 \%$ & $-13.0 \%$ \\
\hline 2013 & $14.4 \%$ & $-6.4 \%$ & $18.4 \%$ & $-22.3 \%$ & $24.4 \%$ & $3.3 \%$ \\
\hline 2014 & $12.3 \%$ & $-11.1 \%$ & $13.3 \%$ & $-24.4 \%$ & $21.9 \%$ & $-5.0 \%$ \\
\hline 2015 & $10.5 \%$ & $-11.7 \%$ & $11.5 \%$ & $-10.2 \%$ & $21.4 \%$ & $8.3 \%$ \\
\hline 2016 & $9.5 \%$ & $-5.3 \%$ & $9.9 \%$ & $-9.6 \%$ & $21.6 \%$ & $10.0 \%$ \\
\hline
\end{tabular}

Source: authors' calculation based on data from Central bank of Bosnia and Herzegovina, 2017; Central bank of Montenegro, 2017; National bank of Serbia, 2017.

Table 2 Share of capital in total sources of financing of banking sector and annual growth rate of stocks (\%)

\begin{tabular}{|c|c|c|c|c|c|c|}
\hline \multirow[t]{2}{*}{ Year } & \multicolumn{2}{|c|}{ Bosnia and Herzegovina } & \multicolumn{2}{|l|}{ Serbia } & \multicolumn{2}{|l|}{ Montenegro } \\
\hline & $\begin{array}{l}\text { Share in } \\
\text { total }\end{array}$ & $\begin{array}{l}\text { Growth } \\
\text { rate }\end{array}$ & $\begin{array}{l}\text { Share in } \\
\text { total }\end{array}$ & $\begin{array}{l}\text { Growth } \\
\text { rate }\end{array}$ & $\begin{array}{l}\text { Share in } \\
\text { total }\end{array}$ & $\begin{array}{l}\text { Growth } \\
\text { rate }\end{array}$ \\
\hline $\begin{array}{l}2003-2008 \text { aver- } \\
\text { age }\end{array}$ & $13.2 \%$ & $11.4 \%$ & $19.5 \%$ & $34.1 \%$ & $15.1 \%$ & $25.2 \%$ \\
\hline 2008 & $11.0 \%$ & $15.4 \%$ & $22.6 \%$ & $41.4 \%$ & $8.4 \%$ & $17.9 \%$ \\
\hline 2009 & $11.2 \%$ & $2.1 \%$ & $288.7 \%$ & $19.6 \%$ & $11.0 \%$ & $18.7 \%$ \\
\hline 2010 & $12.1 \%$ & $8.1 \%$ & $390.0 \%$ & $19.4 \%$ & $10.6 \%$ & $-6.3 \%$ \\
\hline 2011 & $14.2 \%$ & $21.4 \%$ & $440.5 \%$ & $19.5 \%$ & $10.9 \%$ & $-1.8 \%$ \\
\hline 2012 & $14.6 \%$ & $4.8 \%$ & $465.2 \%$ & $18.8 \%$ & $10.3 \%$ & $-5.4 \%$ \\
\hline 2013 & $14.5 \%$ & $4.9 \%$ & $497.3 \%$ & $17.8 \%$ & $13.2 \%$ & $35.1 \%$ \\
\hline 2014 & $14.2 \%$ & $1.8 \%$ & $0.0 \%$ & $17.1 \%$ & $14.0 \%$ & $12.9 \%$ \\
\hline 2015 & $14.2 \%$ & $4.3 \%$ & $0.0 \%$ & $0.0 \%$ & $13.4 \%$ & $5.6 \%$ \\
\hline 2016 & $14.5 \%$ & $6.2 \%$ & $0.0 \%$ & $0.0 \%$ & $13.1 \%$ & $6.9 \%$ \\
\hline
\end{tabular}

Source: authors' calculation based on data from Central bank of Bosnia and Herzegovina, 2017;

Central bank of Montenegro, 2017; National bank of Serbia, 2017. 
Table 3 Number of banks and share of foreign capital in banking sector

\begin{tabular}{|l|l|l|l|l|r|r|}
\hline Year & Country & $\begin{array}{l}\text { Banks with } \\
\text { foreign } \\
\text { capital }\end{array}$ & $\begin{array}{l}\text { Banks with } \\
\text { domestic } \\
\text { private } \\
\text { capital }\end{array}$ & $\begin{array}{l}\text { Banks with } \\
\text { domestic } \\
\text { state capital }\end{array}$ & $\begin{array}{l}\text { Total num- } \\
\text { ber of banks }\end{array}$ & $\begin{array}{l}\text { Share of } \\
\text { foreign cap- } \\
\text { ital in total } \\
\text { capital }\end{array}$ \\
\hline 2008 & 21 & 7 & 2 & 30 & $87.2 \%$ \\
& $\begin{array}{l}\text { Bosnia and Her- } \\
\text { zegovina }\end{array}$ & 9 & 2 & - & 11 & $78.0 \%$ \\
\hline & Montenegro & 20 & 6 & 8 & 34 & $75.0 \%$ \\
\hline 2016 & Serbia & 16 & 8 & 2 & 26 & $82.4 \%$ \\
\hline & Bosnia and Her- & 7 & 5 & 0 & 12 & $\mathrm{n} / \mathrm{a}$. \\
\hline & Megovina & 22 & 6 & 2 & 30 & $79.4 \%$ \\
\hline
\end{tabular}

Source: authors' work based on data from Banking Agency of Federation of Bosnia and Herzegovina Publications (n.d.); Banking Agency of Republic Srpska Publications (n.d.), National Bank of Serbia Quarterly Reports (n.d.), International Monetary Fund (2008) and International Monetary Fund (2016).

In 2008 the share of foreign capital in banks was high, 87.2\% in Bosnia and Herzegovina, 78.0\% in Montenegro, and 75.0\% in Serbia. The dominance of foreign-owned banks can be seen in Table 3. As is evident from Table 3, the banking sectors of the observed countries were mainly foreign owned before the GFC and this remains the case. For Montenegro, the exact share of foreign capital was not available, but the number of foreign owned banks has remained higher than the number of domestic banks throughout the observed period.

In late 2008 and early 2009, there was a fear that foreign owned banks would withdraw from the region so as to decrease their exposure. This would have caused a complete collapse of the financial system in South-eastern Europe. Fortunately, this did not occur. The European Investment Bank, European Bank for Reconstruction and Development, European Commission, World Bank, and International Monetary Fund all lent their support to the banking sectors of South-eastern Europe. Under an agreement commonly known as the Vienna Initiative, foreign banks committed to maintaining their levels of exposure at 2008 levels and to support their subsidiaries (European International Bank, n/d).

One of the most important indicators of banking sector health is the capital adequacy ratio. Capital adequacy ratio is calculated by putting capital in relation to risk weighted asset (Van Greuning and Brajovic-Bratanovic, 2009). The regulatory requirements for minimal capital adequacy ratio did not change after the GFC and in Bosnia and Herzegovina and Serbia it is $12.0 \%$, while in Montenegro it is $10.0 \%$. 
Figure 1 Capital adequacy ratio of banking sector

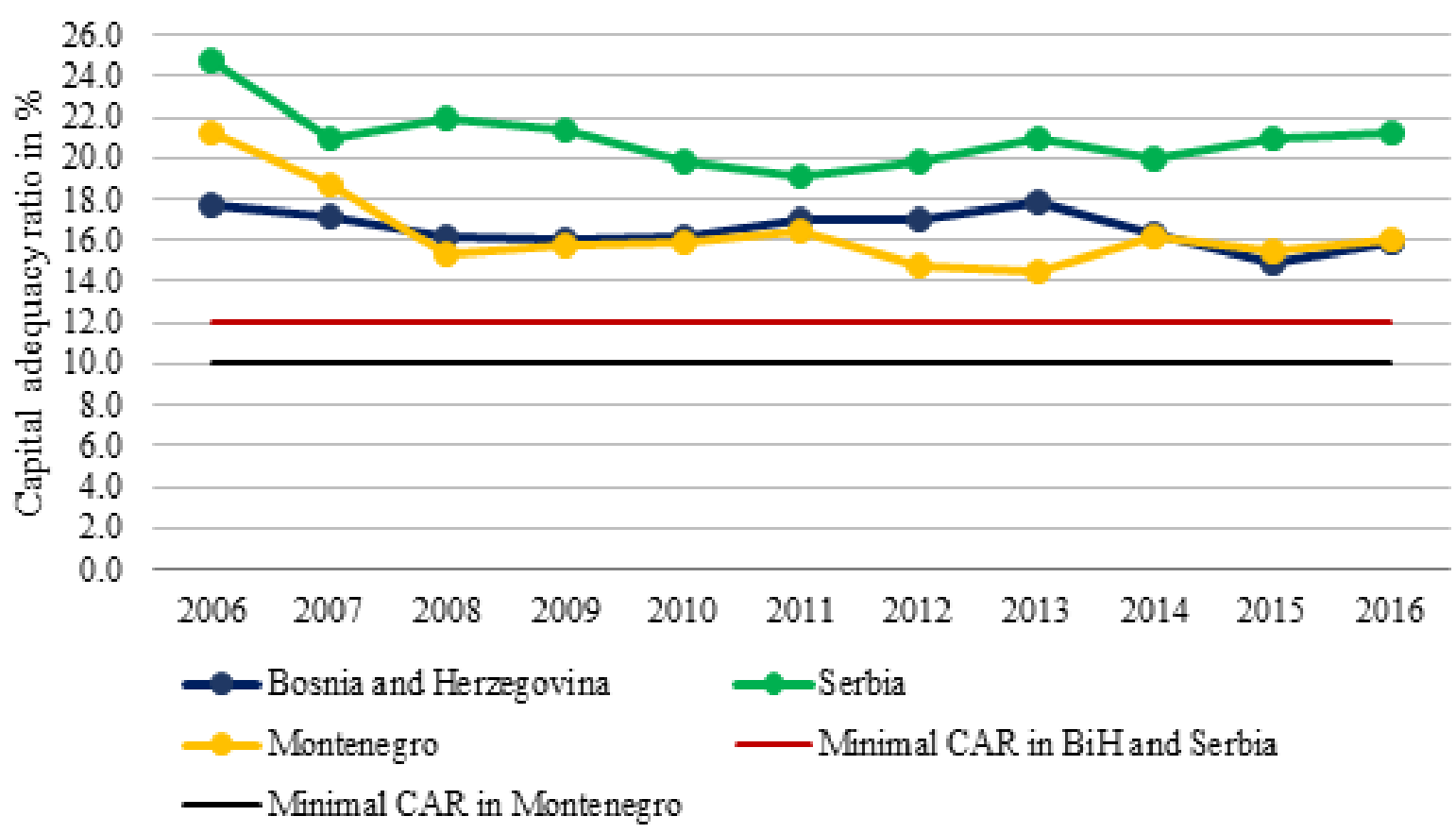

As presented in Figure 1, through all the observed period, the banking sectors at the aggregated level did not have problems with adequate capitalization. This is in line with Cocozza et al. (2011) who show that during the GFC the banking sector in the region had solid capital buffers.

\section{DEPOSITS}

Domestic deposits represent the largest source of financing for the banking sectors of the selected countries. In 2008, deposits made up 57.2\% of banking sector financing sources in Bosnia and Herzegovina. The figure was $58.1 \%$ in Serbia and it was $60.1 \%$ in Montenegro.

In the period from 2003-2007, the countries experienced strong growth in deposits. The average annual growth of total deposits ranged from 22.0\% in Bosnia and Herzegovina and 29.2\% in Serbia to $64.9 \%$ in Montenegro. However, one of the first signs of the GFC spilling over to the region was a deposit outflow in the last quarter of 2008, which caused a slowdown in deposit growth or even negative growth depending on the country. Bosnia and Herzegovina and Montenegro experienced sharp declines and negative growth rates, $-1.8 \%$ and $-4.8 \%$ respectively, while Serbia recorded a slowdown from $54.5 \%$ to $6.8 \%$. A probable reason for this deposit outflow was the not-so-distant memory of billions worth of savings, mostly denominated in German marks, being lost during the collapse of Yugoslavia. Fortunately, the outflow was of a temporary nature and did not have a major effect on banking systems. 
Table 4 Share of deposits in total sources of financing and growth rates of stocks (\%)

\begin{tabular}{|c|c|c|c|c|c|c|}
\hline Year & Bosnia and & Herzegovina & Serbia & & Montenegr & \\
\hline & $\begin{array}{l}\text { Share in } \\
\text { total }\end{array}$ & $\begin{array}{l}\text { Growth } \\
\text { rate }\end{array}$ & $\begin{array}{l}\text { Share in } \\
\text { total }\end{array}$ & $\begin{array}{l}\text { Growth } \\
\text { rate }\end{array}$ & $\begin{array}{l}\text { Share in } \\
\text { total }\end{array}$ & $\begin{array}{l}\text { Growth } \\
\text { rate }\end{array}$ \\
\hline $\begin{array}{l}2003-2008 \text { aver- } \\
\text { age }\end{array}$ & $59.2 \%$ & $22.0 \%$ & $64.3 \%$ & $29.2 \%$ & $65.0 \%$ & $64.9 \%$ \\
\hline 2008 & $57.2 \%$ & $-1.8 \%$ & $58.1 \%$ & $6.8 \%$ & $60.1 \%$ & $-4.8 \%$ \\
\hline 2009 & $58.6 \%$ & $1.8 \%$ & $52.7 \%$ & $7.1 \%$ & $60.3 \%$ & $-8.3 \%$ \\
\hline 2010 & $60.3 \%$ & $3.6 \%$ & $53.4 \%$ & $4.3 \%$ & $60.8 \%$ & $-1.9 \%$ \\
\hline 2011 & $60.5 \%$ & $3.7 \%$ & $54.4 \%$ & $10.4 \%$ & $64.7 \%$ & $1.5 \%$ \\
\hline 2012 & $60.1 \%$ & $1.4 \%$ & $59.1 \%$ & $-0.5 \%$ & $70.5 \%$ & $9.0 \%$ \\
\hline 2013 & $61.8 \%$ & $8.1 \%$ & $58.4 \%$ & $3.3 \%$ & $70.9 \%$ & $5.9 \%$ \\
\hline 2014 & $63.9 \%$ & $7.9 \%$ & $63.2 \%$ & $3.8 \%$ & $73.6 \%$ & $10.0 \%$ \\
\hline 2015 & $66.3 \%$ & $7.5 \%$ & $72.0 \%$ & $3.5 \%$ & $75.6 \%$ & $13.7 \%$ \\
\hline 2016 & $68.0 \%$ & $7.4 \%$ & $67.8 \%$ & $9.2 \%$ & $75.8 \%$ & $9.4 \%$ \\
\hline
\end{tabular}

Source: authors' calculation based on data from Central bank of Bosnia and Herzegovina, 2017;

Central bank of Montenegro, 2017; National bank of Serbia, 2017.

Table 5 Sectoral structure of total deposits in Bosnia and Herzegovina and annual growth rates of stocks (in \%)

\begin{tabular}{|c|c|c|c|c|c|c|}
\hline \multirow[t]{2}{*}{ Year } & \multicolumn{2}{|c|}{ Household deposits } & \multicolumn{2}{|c|}{$\begin{array}{l}\text { Non-financial corpora- } \\
\text { tions deposits }\end{array}$} & \multicolumn{2}{|c|}{ Other deposits } \\
\hline & $\begin{array}{l}\text { Share in } \\
\text { total }\end{array}$ & $\begin{array}{l}\text { Growth } \\
\text { rates }\end{array}$ & $\begin{array}{l}\text { Share in } \\
\text { total }\end{array}$ & $\begin{array}{l}\text { Growth } \\
\text { rates }\end{array}$ & $\begin{array}{l}\text { Share in } \\
\text { total }\end{array}$ & $\begin{array}{l}\text { Growth } \\
\text { rates }\end{array}$ \\
\hline 2006 & 46.8 & 28.6 & 30.5 & 24.5 & 22.6 & 29.1 \\
\hline 2008 & 43.8 & 0.8 & 25.6 & 13.1 & 25.7 & -18.0 \\
\hline 2010 & 51.8 & 14.5 & 24.7 & 0.2 & 20.3 & -13.2 \\
\hline 2012 & 57.1 & 6.7 & 21.1 & -4.3 & 18.0 & -5.7 \\
\hline 2014 & 58.8 & 8.1 & 22.0 & 2.4 & 17.6 & 15.4 \\
\hline 2016 & 60.1 & 8.1 & 23.3 & 5.6 & 17.4 & 7.4 \\
\hline
\end{tabular}

Source: authors' calculation based on data from Central bank of Bosnia and Herzegovina, 2017.

Table 6 Sectoral structure of total deposits in Serbia and annual growth rates of stocks (in \%)

\begin{tabular}{|l|l|l|l|l|l|r|}
\hline Year & \multicolumn{2}{|l|}{ Household deposits } & \multicolumn{2}{l|}{$\begin{array}{l}\text { Non-financial corporations } \\
\text { deposits }\end{array}$} & \multicolumn{2}{l|}{ Other deposits } \\
\hline & \multicolumn{2}{|l|}{$\begin{array}{l}\text { Share in } \\
\text { total }\end{array}$} & $\begin{array}{l}\text { Growth } \\
\text { rates }\end{array}$ & \multicolumn{2}{l}{$\begin{array}{l}\text { Share in } \\
\text { total }\end{array}$} & \multicolumn{2}{l}{$\begin{array}{l}\text { Growth } \\
\text { rates }\end{array}$} & \multicolumn{2}{l}{$\begin{array}{l}\text { Share in } \\
\text { total }\end{array}$} & \multicolumn{2}{l}{$\begin{array}{l}\text { Growth } \\
\text { rates }\end{array}$} \\
\hline 2006 & 51.7 & 37.2 & 40.3 & 36.8 & 7.9 & 46.1 \\
\hline 2008 & 52.6 & 9.4 & 35.7 & -10.1 & 11.7 & 100.1 \\
\hline 2010 & 63.2 & 15.2 & 28.8 & -5.8 & 8.1 & -22.9 \\
\hline 2012 & 65.3 & 4.2 & 28.5 & -8.0 & 6.1 & -9.2 \\
\hline 2014 & 66.9 & 4.0 & 28.7 & 10.4 & 4.3 & -27.1 \\
\hline 2016 & 63.1 & 5.8 & 33.2 & 16.6 & 3.7 & 6.6 \\
\hline
\end{tabular}

Source: authors' calculation based on data from National Bank of Serbia, 2017. 
Table 7 Sectoral structure of total deposits in Montenegro and and annual growth rates of stocks (in \%)

\begin{tabular}{|c|c|c|c|c|c|c|}
\hline \multirow[t]{2}{*}{ Year } & \multicolumn{2}{|c|}{ Household deposits } & \multicolumn{2}{|c|}{$\begin{array}{l}\text { Non-financial corporations } \\
\text { deposits }\end{array}$} & \multicolumn{2}{|c|}{ Other deposits } \\
\hline & $\begin{array}{l}\text { Share in } \\
\text { total }\end{array}$ & $\begin{array}{l}\text { Growth } \\
\text { rates }\end{array}$ & $\begin{array}{l}\text { Share in } \\
\text { total }\end{array}$ & $\begin{array}{l}\text { Growth } \\
\text { rates }\end{array}$ & $\begin{array}{l}\text { Share in } \\
\text { total }\end{array}$ & $\begin{array}{l}\text { Growth } \\
\text { rates }\end{array}$ \\
\hline 2006 & 46.4 & 184.1 & 34.6 & & 19.0 & \\
\hline 2008 & 43.0 & -16.0 & 35.3 & -4.5 & 21.7 & 28.4 \\
\hline 2010 & 53.2 & 12.8 & 28.0 & -16.8 & 18.8 & -11.0 \\
\hline 2012 & 57.9 & 11.0 & 29.7 & 10.3 & 12.4 & -1.9 \\
\hline 2014 & 57.7 & 7.6 & 32.1 & 20.2 & 10.2 & -3.4 \\
\hline 2016 & 53.4 & 6.6 & 39.2 & 22.3 & 7.3 & -20.0 \\
\hline
\end{tabular}

Source: authors' calculations based on data from Central bank of Montenegro, 2017.

As shown in Table 4, between 2009 and 2013, deposit activity was quite modest or even negative. From 2013, until the end of the observed period, the banking sectors of all three countries recorded accelerated growth rates. In addition, they all saw increases in the shares of domestic deposits in total financing sources in the banking sector balance sheets compared to 2008. At the end of 2016 , the share of domestic deposits in the banking sector balance sheet was $68.0 \%$ in Bosnia and Herzegovina, 67.8\% in Serbia, and 75.8\% in Montenegro.

The results show that household sector deposits have the biggest share in total deposits in all three countries (Tables 5-7). Despite the deposit outflow of the last quarter of 2008, household deposits in Bosnia and Herzegovina did not record a negative growth in any year during the observed period, and both stocks of the household deposits and their share in total deposits kept an increasing trend. On the other hand, comparing 2008 and 2016, deposits of non-financial corporations and other deposits decreased their shares in total deposits, but recorded positive annual growth rates recently. Similarly, the banking sector in Serbia recorded lower positive annual changes (9.4\%), but kept an increasing trend in terms of the stocks of the household deposits and their share in total deposits. But, unlike the banking sector in Bosnia and Herzegovina where the household sector is the main driver of total deposits, in Serbia it appears that sector of non-financial corporations is recording much higher annual growth of deposits then households in the last few years, giving higher contribution to growth of total deposits.

However, the banking sector of Montenegro was faced with a declining trend of household deposits two years in a row, $-16.0 \%$ in 2008 and $-1.5 \%$ in 2009 , after which the growth turned positive again. Similarly to trends in Serbia, deposits of non-financial corporations are recording much faster annual growth then household sector deposits.

Although the intensity of deposit activity is lower compared to pre-GFC period, it is still better than credit activity. Domestic deposits recorded increasing shares in balance sum, meaning that they are a more important source of financing after the GFC than before. The main driver of expanding deposit base in Bosnia and Herzegovina is household sector. However, in the last few years it seems that in Serbia non-financial corporations had higher contribution to total deposit growth than household sector. The Montenegro situation is similar. This means that besides households' deposits, the driver of total deposit growth in these two countries is deposits of non-financial corporations, which is a surprising result of this research. 


\section{CREDIT ACTIVITY AND BANKING SECTOR ASSETS}

\section{BANK LOANS TO DOMESTIC SECTORS}

Prior to the GFC, the banking sector of South-eastern Europe was experiencing a credit boom. The average annual credit growth rate in the 2003-2008 period for Bosnia and Herzegovina was $22.1 \%$, for Serbia $37.3 \%$, and for Montenegro $77.9 \%$. The main driver of the credit growth was high demand from the private sector (households and non-financial corporations).

Table 8 Annual growth rate of total loan stocks in \%

\begin{tabular}{|l|r|r|r|}
\hline Period & $\begin{array}{l}\text { Bosnia and } \\
\text { Herzegovina }\end{array}$ & Serbia & Montenegro \\
\hline Average 2003-2008 & $22.1 \%$ & $37.3 \%$ & $77.9 \%$ \\
\hline 2008 & $23.0 \%$ & $36.0 \%$ & $24.8 \%$ \\
\hline 2009 & $-3.2 \%$ & $16.3 \%$ & $-13.7 \%$ \\
\hline 2010 & $3.4 \%$ & $27.2 \%$ & $-7.9 \%$ \\
\hline 2011 & $5.4 \%$ & $8.0 \%$ & $-9.7 \%$ \\
\hline 2012 & $4.3 \%$ & $9.5 \%$ & $-4.6 \%$ \\
\hline 2013 & $3.1 \%$ & $-4.1 \%$ & $7.7 \%$ \\
\hline 2014 & $2.8 \%$ & $3.4 \%$ & $-3.0 \%$ \\
\hline 2015 & $2.4 \%$ & $2.9 \%$ & $1.9 \%$ \\
\hline 2016 & $2.0 \%$ & $2.6 \%$ & $6.7 \%$ \\
\hline
\end{tabular}

Source: authors' calculation based on data from Central bank of Bosnia and Herzegovina, 2017; Central bank of Montenegro, 2017; National bank of Serbia, 2017.

The GFC had a serious impact on credit activity. In 2009, credit activity was negative on annual level in Bosnia and Herzegovina and Montenegro, $-3.2 \%$ and $-13.7 \%$, respectively (Table 8). In Serbia, a slowdown was recorded, from $36.0 \%$ in 2008 to $16.3 \%$ in 2009 . Credit activity following 2009 has been very different in the observed countries. While in Bosnia and Herzegovina recorded modest growth, Serbia has witnessed significant volatility. On the other hand, Montenegro has seen a very slight, but steady, decline in credit activity. However, at the end of the observed period, all countries recorded low, but positive, annual growth. Nevertheless, it is evident that credit activity did not return to pre-GFC levels. Prolonged weak macroeconomic conditions continuing during the following years influenced behaviour and creditworthiness of borrowers and behaviour of banks. Households are more prone to saving then spending, which decreased demand for bank loans.

\section{NON-PERFORMING LOANS}

The banking sector in Bosnia and Herzegovina had a clear decreasing trend before the GFC hit the region when non-performing loans started to rise. High share of poor loans can be credited to negative or low economic activity affecting the ability of companies to meet their obligations and decreased income of households. 
Figure 2 Non-performing loans in Bosnia and Herzegovina

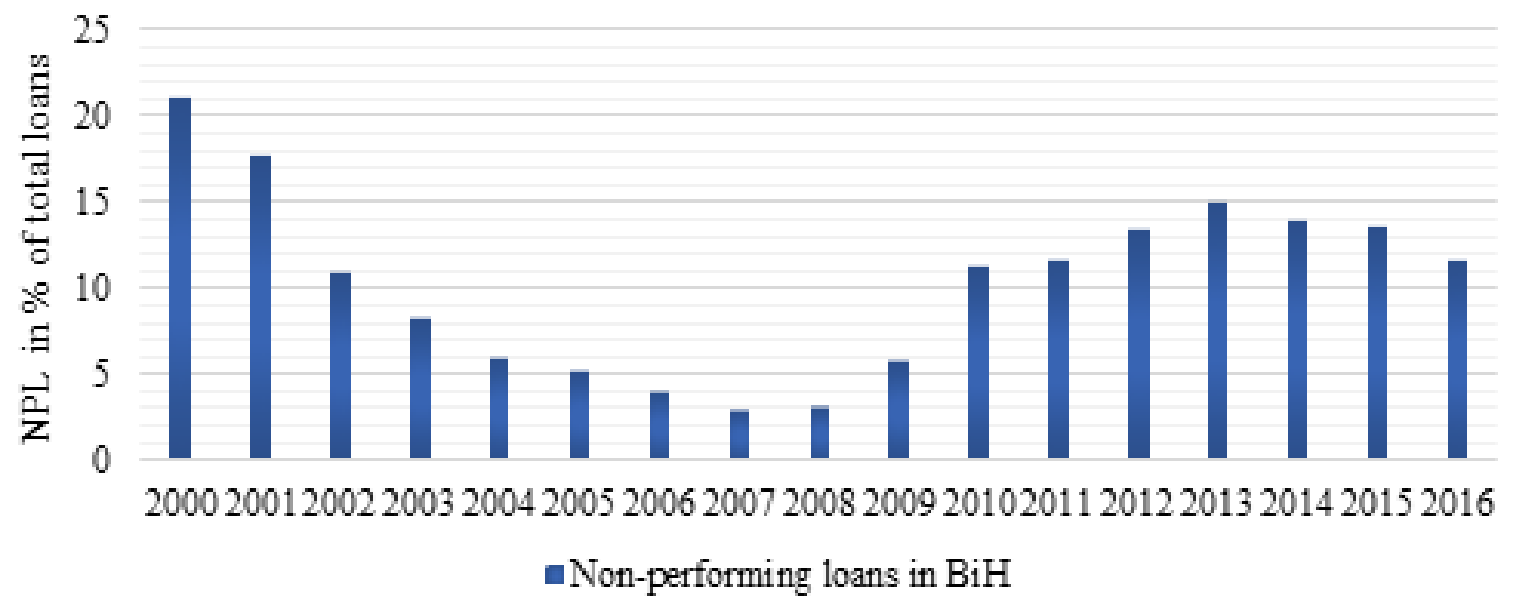

Source: authors' work based on data from Central Bank of Bosnia and Herzegovina, 2017

Figure 3 Share of non-performing loans in Serbia

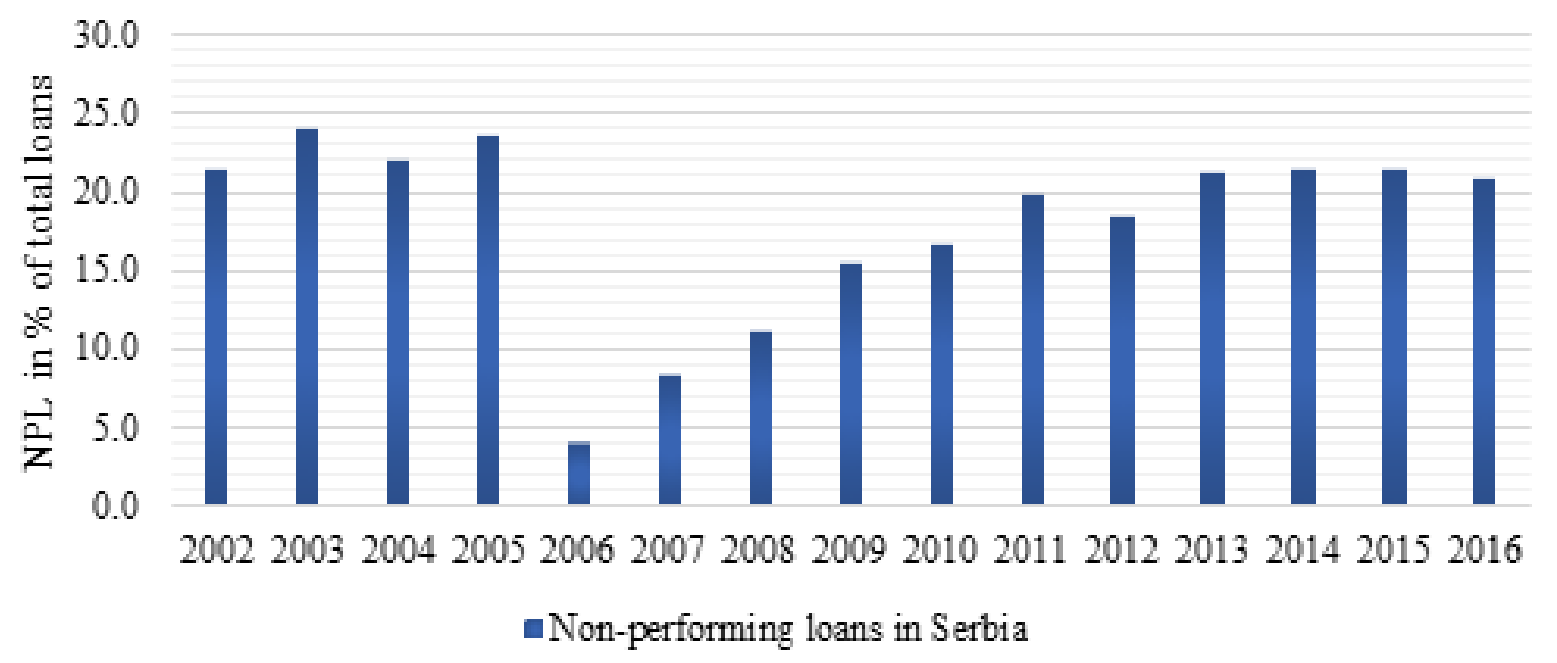

Source: authors' work based on data from The World Bank Data, 2017

Following a sharp decline in 2006, the quality of credit portfolios started to deteriorate again in Serbia. Data on non-performing loans for Montenegro is available from 2004. Similarly, to Serbia, improvement in the quality of loan portfolios was recorded only in 2006. The first signs of the GFC appeared in the last quarter of 2008, which might have triggered an upward trend. It seems that after 2013 banks became better at managing their credit portfolios and began clearing out bad assets.

Results regarding non-performing loans and decreased financing from abroad in the form of foreign liabilities of banking sectors confirm the findings of the previous study by Roaf et al. (2014) of credit activity limitations. The rise of non-performing loans can be related to economic conditions in the country that affect borrowers' repayment capacity (Klein, 2013). Banking sectors of all three countries are operating in worse economic conditions than prior to 2009, and persistently have nonperforming loans higher than in the pre-GFC period. However, there is a convincing improving trend in Bosnia and Hercegovina and Montenegro, which cannot be said for the banking sector in Serbia. 


\section{BANKING SECTOR ASSETS SIZE AND ANNUAL GROWTH}

Table 9 Total assets to GDP and annual growth rate of stocks (in \%)

\begin{tabular}{|l|r|r|r|r|r|r|}
\hline Year & \multicolumn{3}{|l|}{ Bosnia and Herzegovina } & \multicolumn{2}{l|}{ lerbia } & \multicolumn{2}{l|}{ Montenegro } \\
\hline & \% of GDP & Growth rate & \% of GDP & Growth rate & \% of GDP & Growth rate \\
\hline 2008 & $81.3 \%$ & $7.8 \%$ & $69.8 \%$ & $30.5 \%$ & $106.6 \%$ & $11.2 \%$ \\
\hline 2009 & $83.3 \%$ & $-0.5 \%$ & $81.1 \%$ & $18.1 \%$ & $100.8 \%$ & $-8.6 \%$ \\
\hline 2010 & $82.0 \%$ & $0.7 \%$ & $89.4 \%$ & $2.9 \%$ & $94.2 \%$ & $-2.7 \%$ \\
\hline 2011 & $82.0 \%$ & $3.4 \%$ & $85.2 \%$ & $8.4 \%$ & $86.1 \%$ & $-4.5 \%$ \\
\hline 2012 & $83.7 \%$ & $2.0 \%$ & $88.1 \%$ & $-8.4 \%$ & $88.3 \%$ & $-0.1 \%$ \\
\hline 2013 & $86.3 \%$ & $5.2 \%$ & $81.2 \%$ & $4.5 \%$ & $88.0 \%$ & $5.4 \%$ \\
\hline 2014 & $88.1 \%$ & $4.3 \%$ & $84.6 \%$ & $-4.0 \%$ & $90.7 \%$ & $6.0 \%$ \\
\hline 2015 & $87.1 \%$ & $3.7 \%$ & $84.8 \%$ & $-9.3 \%$ & $95.8 \%$ & $10.7 \%$ \\
\hline 2016 & $88.9 \%$ & $4.6 \%$ & $85.6 \%$ & $16.0 \%$ & $101.6 \%$ & $9.2 \%$ \\
\hline
\end{tabular}

Source: authors' calculations based on data from National Accounts Main Aggregates Database, 2016; IMF Data Accesses to Macroeconomic and Financial Data. (n.d.); Central Bank of Bosnia and Herzegovina, 2017; National Bank of Serbia, 2017; Central Bank of Montenegro, 2017.

Table 10 Foreign owned bank assets in total bank assets

\begin{tabular}{|l|l|r|}
\hline Year & Country & $\begin{array}{l}\text { Banking assets in foreign owned } \\
\text { banks, \% of total bank assets }\end{array}$ \\
\hline 2008 & Bosnia and Herzegovina & $95.0 \%$ \\
\hline & Montenegro & n.a. \\
\hline & Serbia & $67.0 \%$ \\
\hline 2016 & Bosnia and Herzegovina & $85.7 \%$ \\
\hline & Montenegro & $79.2 \%$ \\
\hline & Serbia & $69.9 \%$ \\
\hline
\end{tabular}

Source: authors' work based on data from Federal Banking Agency of Bosnia and Herzegovina Publications (n.d.); Banking Agency of Republic Srpska Publications (n.d.); National Bank of Serbia Quarter and Annual Report. (n.d.); International Monetary Fund Financial System Stability Report (2008) and International Monetary Fund (2016).

Structural reforms in the banking sectors prior to the GFC resulted in fast growth of banking sector assets. From 2003-2008 the average annual growth rate of banking sector assets in Bosnia and Herzegovina was 22.1\%, 30.7\% in Serbia, and 61.7\% in Montenegro. Naturally, 2009 was a year of change brought about by the GFC. The rapid rate of annual growth of the banking sectors' assets prior to the GFC was replaced by sluggish and unstable growth after the crisis (see Table 9).

Comparing ratio on banking sector assets to GDP between 2008 and 2016 one can conclude that there was a continuous trend of financial deepening in Bosnia and Herzegovina and Serbia. However, this is not because of convincing growth of banking sector assets and financial sector deepening, but rather because economic growth was poor. It should be kept in mind that using only ratios of banks' asset to GDP to measure size and depth of banking sector does not give us too much information. The size of banking sector should be assessed from a wider industry policy perspective (Schoenmaker and Werkhoven, 2012). However, this is a topic for some other research. The analysis of the ownership structures of the banking sectors confirms earlier findings that major portions of them are foreign-owned. 


\section{RETURN ON ASSETS AND EQUITY}

Finally, the question of whether profitability recovered to its pre-GFC levels will be answered. Return on assets and return on equity (hereinafter ROA and ROE) were used as indicators of profitability. Although ROA and ROE cannot provide sufficient grounds for a deep analysis, they can serve as indicators of general trends.

Table 11 Return on assets and return on equity

\begin{tabular}{|c|c|c|c|c|c|c|}
\hline \multirow[t]{2}{*}{ Year } & \multicolumn{2}{|c|}{ Bosnia and Herzegovina } & \multicolumn{2}{|l|}{ Serbia } & \multicolumn{2}{|l|}{ Montenegro } \\
\hline & $\mathrm{ROA}$ & $\mathrm{ROE}$ & $\mathrm{ROA}$ & $\mathrm{ROE}$ & ROA & $\mathrm{ROE}$ \\
\hline 2006 & 1.1 & 10.6 & 1.8 & 9.6 & 0.6 & 5.5 \\
\hline 2007 & 1.0 & 10.5 & 1.9 & 8.9 & 0.5 & 5.6 \\
\hline 2008 & 0.5 & 4.9 & 1.6 & 7.1 & -0.3 & -4.2 \\
\hline 2009 & 0.2 & 2.3 & 0.7 & 3.4 & 0.3 & 3.5 \\
\hline 2010 & -0.6 & -4.9 & 0.8 & 4.0 & -2.5 & -23.4 \\
\hline 2011 & 0.7 & 5.8 & 0.9 & 4.4 & -0.7 & -6.2 \\
\hline 2012 & 0.7 & 5.1 & 0.6 & 2.9 & -2.5 & -23.4 \\
\hline 2013 & -0.1 & -0.5 & -0.4 & -1.9 & 0.0 & 0.4 \\
\hline 2014 & 0.8 & 5.4 & 0.6 & 2.9 & 1.0 & 6.9 \\
\hline 2015 & 0.3 & 2.0 & 0.3 & 1.6 & 0.3 & 1.7 \\
\hline 2016 & 1.1 & 7.3 & 0.7 & 3.4 & 0.7 & 5.0 \\
\hline
\end{tabular}

Source: authors' work based on from Global Financial Development, 2017; Central Bank of Bosnia and Herzegovina, 2017; National Bank of Serbia, 2017; Central Bank of Montenegro, 2017.

The banking sectors' profitability started to decline in 2008, though in Bosnia and Herzegovina and Serbia it was just lower compared to the previous year, while in Montenegro it was actually negative, so Živkovićs (2011) findings related to profitability and crisis could not be confirmed. It seems that the banking sector in Montenegro experienced the biggest hit on profitability compared to the other two neighbouring countries. The worst period was 2010-2012 when, for three years in a row, financial result on aggregated level was negative. After this period, the banking sectors managed to generate positive ROAs and ROEs, but results are still weak. High share of non-performing loans and lower level of profitability are characteristics of the banking sector in Serbia since 2008, as well as in Bosnia and Herzegovina. The banking sector in Bosnia and Herzegovina had a particularly disastrous 2010 and 2013 when it comes to profitability, while in Serbia a negative financial result was registered only in 2013. This fall in profitability can be related to the rises in non-performing loans in all three countries and poor credit growth.

Findings on profitability lead to the overall conclusion that the banking sectors' profitability has been low since 2008 and this could be related to higher shares of non-performing loans in credit portfolios. Alper and Anbar (2011) examine the case of the ten biggest banks in Turkey and find that quality of assets had significant impact on return on assets. Dumičić and Ljubaj (2017) reach a similar conclusion for the banking sector in Croatia for the period 2009-2015 when ROA started to drop as soon as non-performing loans given to the corporate sector started to rise.

For many consecutive years, the banking sectors have a share of non-performing loans higher than $10 \%$ in all three countries. 


\section{CONCLUSION}

The aim of this research was to examine data related to the banking sectors, compare them to the pre-GFC period, and answer the main research question: Have banking sectors in Bosnia and Herzegovina, Montenegro and Serbia recovered from the global financial crisis and do they perform better currently?

Findings show that credit activity did not recover after the GFC. The rapid rate of annual growth of bank loans prior to the GFC was replaced by sluggish and unstable growth after the GFC. Factors could be found on demand and supply side of bank loans. Lower demand for banks loans is primarily caused by the change of household attitudes towards consumption. Lower supply of bank loans is primarily caused by more cautious lending due to high level of non-performing loans after the GFC meaning that the credit risk is high and due to limited funding from abroad. However, the weak economic performance in all three countries is the underlying cause of these trends.

The results show that after the GFC the sources of funding changed. Before the GFC, foreign liabilities in form of loans and deposits from parent companies from abroad were important sources of financing for the banking sectors in Bosnia and Herzegovina, Montenegro, and Serbia since foreign-owned banks make up large parts of the banking sectors. After the GFC, foreign-owned banks started to deleverage, meaning banks were repaying foreign obligations to parent companies, without issuing new ones. On the other hand, the shares of capital in total sources of funding did not experience major changes. Parent companies did not withdraw capital from subsidiaries in the region. The share of deposits in total sources of financing increased, meaning that banks more rely on domestic deposits.

Every following year after the GFC, the banking sector in Bosnia and Herzegovina recorded much higher levels of non-performing loans then in pre-GFC period. However, there is a promising downward trend during the last few years. The results describe a similar scenario for banking sector in Montenegro. On the other hand, it seems that the banking sector in Serbia has a prolonged problem with non-performing loans in their assets. Even before the GFC this was a major problem, except for 2006. It is recommended for all three countries that regulation related to resolution of non-performing assets should be improved in a way that helps banks to better deal with this problem.

The results show that deposit activity is not as low as credit activity. Nevertheless, it is not as intense as it was before the GFC. If comparing annual growth rates of total deposits recorded in years before the GFC to the ones recorded after the GFC, it becomes evident that the growth is much lower afterwards.

The main driver of deposit growth in Bosnia and Herzegovina before and after the GFC is household sector. However, in Montenegro and Serbia, the household sector was the major driver until the last few years, when deposits on non-financial corporations started to record much higher annual growth rates compared to deposits of households. This is an interesting finding and it would be interesting to investigate it with more detailed data on factors that influence behaviour of nonfinancial corporations and households. This is a worthwhile topic for future research.

The results regarding profitability show that profitability has been low since 2008. For years after the first wave of GFC, banking sectors in selected countries were recording either negative profitability or lower than before the GFC, depending on the country. However, results for 2016 are promising, but it is not clear whether this improvement is a one-time event, since there is no clear trend after the crisis. 


\section{REFERENCES}

1. Alper, D. and Anbar, A. (2011) Bank Specific and Macroeconomic Determinants of Commercial Bank Profitability: Empirical Evidence from Turkey. Business and economics research journal. [Online] Vol.2(2), pp. 139 - 152. http://www.berjournal.com/bank-specific-and-macroeconomicdeterminants-of-commercial-bank-profitability-empirical-evidence-from-turkey-2 Available: [Accessed: 17 July 2017].

2. Banking Agency of Federation of Bosnia and Herzegovina Publications. (n.d.) [Online] Available: $h t t p: / / f b a . b a / i n d e x . p h p ? p a g e=37$ [Accessed: 15 July 2017].

3. Banking Agency of Republic Srpska publications. (n.d.) [Online] Available: https://abrs.ba/en/ izvjestaji/c3 [Accessed: 15 July 2017].

4. Barjaktarović, L. (2009) Transformation of the domestic bank into modern European bank. (Transfomacija domaće banke u savremenu evropsku banku). [Online] Available: https:// singipedia.singidunum.ac.rs/izdanje/40816-transformacija-domace-banke-u-savremenuevropsku-banku [Accessed: 8 August 2017].

5. Barjaktarović, L., Paunović, M. and Ječmenica, D. (2013) Development of the Banking

6. Sector in CEE Countries - Comparative Analysis. Journal of Central Banking Theory and Practice. [Online] Vol.2(2), pp.93-114. Available: ftp://ftp.repec.org/opt/ReDIF/RePEc/cbk/journl/ vol2no2-6.pdf [Accessed: 20 May 2017].

7. Barisitz, S. (2009) Banking transformation 1980-2006 in Central and Eastern Europe - from communism to capitalism. [Online] Available: http://www.asecu.gr/Seeje/issue13/Barisitz.pdf [Accessed: 1 July 2017].

8. Bartlett, W. and Monastiriotis, V. (2010) South East Europe after the Economic Crisis: A New Dawn or back to Business as Usual? [Online] Available: http://www.lse.ac.uk/europeanInstitute/ research/LSEE/PDFs/Publications/SEE\%20Crisis\%20Book.pdf [Accessed: 17 May 2017].

9. Banking Agency of Federation of Bosnia and Herzegovina Publications. (n.d.) [Online] Available: http://fba.ba/index.php?page=37 [Accessed: 15 July 2017].

10. Banking Agency of Republic Srpska publications. (n.d.) [Online] Available: https://abrs.ba/en/ izvjestaji/c3 [Accessed: 15 July 2017].

11. Bartlett, W. and Prica, I. (2012) The Variable Impact of the Global Economic Crisis in South East Europe. [Online] Available: http://eprints.lse.ac.uk/48037/ [Accessed: 17 May 2017].

12. Borio, C. and Drehmann, M. (2009) Towards an operational framework for financial stability: "fuzzy" measurement and its consequences. [Online] Available: http://www.bis.org/publ/work284. pdf [Accessed: 26 July 2017].

13. Central Bank of Bosnia and Herzegovina (2017) Monetary sector. [Online] Available: http:// statistics.cbbh.ba:4444/Panorama/novaview/SimpleLogin_cr.aspx [Accessed: 6 June 2017].

14. Central Bank of Montenegro (2017) Monetary statistics. [Online] Available: http://www.cb-cg. org/eng/index.php?mn1=statisticsermn2=monetary_statistics [Accessed: 6 June 2017].

15. Cocozza, E., Colabella, A. and Spadafora, F. (2011) The Impact of the Global Crisis on SouthEastern Europe. [Online] Available: http://www.imf.org/en/Publications/WP/Issues/2016/12/31/ The-Impact-of-the-Global-Crisison-South-Eastern-Europe-25452 [Accessed: 21 May 2017].

16. Duisenberg, W. F (2001) The role of financial markets for economic growth. Speech delivered by Dr. Willem F. Duisenberg, President of the European Central Bank, at the Economics Conference "The Single Financial Market: Two Years into EMU” organised by the Oesterreichische Nationalbank in Vienna on 31 May 2001. [Online] Available: https://www.ecb.europa.eu/press/key/date/2001/ html/sp010531.en.html [Accessed: 26 July 2017].

17. Dumičić, M. and Ljubaj, I. (2017) Delayed Credit Recovery in Croatia: Supply or Demand Driven? [Online] Available: https://www.hnb.hr/documents/20182/1770768/w-045.pdf/a98df042-fb3944f3-b6c4-3d1f6cb84354 [Accessed: 18 June 2017]. 
18. Eschenbach, F. (2004) Finance and Growth: A Survey of the Theoretical and Empirical Literature. [Online] Available: https://papers.tinbergen.nl/04039.pdf [Accessed: 2 June 2017].

19. European Bank for Reconstruction and Development (2016) Transition report 2016-2017. [Online] Available: http://www.ebrd.com/transition-report [Accessed: 10 August 2017].

20. European International Bank (n.d) Vienna Initiative. [Online] Available: http://www.eib.org/ projects/regions/vienna-initiative.htm [Accessed: 23 June 2017].

21. Financial stability. (n.d.) [Online] Available: http://www.worldbank.org/en/publication/gfdr/ background/financial-stability [Accessed: 26 July 2017].

22. General Information About the Bank. (n.d.) [Online] Available: http://www.cbbh.ba/Content/ Read/13?lang=en [Accessed: 9 August 2017].

23. Global Financial Development. (2017) [Online] http://data.worldbank.org/data-catalog/globalfinancial-development [Accessed: 27 July 2017].

24. IMF Data Accesses to Macroeconomic and Financial Data. (n.d.) [Online] Available: http://data. imf.org/?sk=388DFA60-1D26-4ADE-B505-A05A558D9A42\&sId=1479329328660 [Accessed: 12 August 2017].

25. International Monetary Fund (2008) Republic of Montenegro: Financial System Stability Assessment. [Online] Available: https://www.imf.org/en/Publications/CR/Issues/2016/12/31/ Republic-of-Montenegro-Financial-System-Stability-Assessment-21670 [Accessed: 15 July 2017].

26. International Monetary Fund (2016) Montenegro Financial System Stability Assessment. [Online] Available: http://www.imf.org/en/Publications/CR/Issues/2016/12/31/Montenegro-FinancialSystem-Stability-Assessment-43820 [Accessed: 15 July 2017].

27. Klein, N. (2013) Non-Performing Loans in CESEE: Determinants and Impact on Macroeconomic Performance. [Online] Available: https://www.imf.org/external/pubs/ft/wp/2013/wp1372.pdf [Accessed: 19 June 2017].

28. Levine, R. (2005) Finance and growth: theory and evidence. In: Aghion, P. and Durlauf, S. N. (ed.) Handbook of Economic Growth. Amsterdam: North Holland Publishing, pp. 865-933.

29. McLeay, M., Radia, A. and Thomas, R. (2014) Money creation in the modern economy. [Online] Available: http://www.bankofengland.co.uk/publications/Documents/quarterlybulletin/2014/ qb14q1prereleasemoneycreation.pdf [Accessed: 20 July 2017].

30. Mešić, D. (2006) Entry of foreign banks in transition countries. (Ulazak stranih banaka u zemlje u tranziciji). Bankarstvo Journal. [Online] (7/8), pp.48-58. Available: http://www.ubs-asb.com/ Default.aspx?tabid=199 [Accessed: 9 August 2017].

31. Mishkin, F. S. (2004) The Economics of Money, Banking, and Financial Markets. 7th ed. Boston: Pearson Addison Wesley.

32. National Accounts Main Aggregates Database (2016) Basic Data Selection. [Online] Available: https://unstats.un.org/unsd/snaama/selbasicFast.asp [Accessed: 28 May 2017].

33. National Bank of Serbia (2017) Monetary and Financial Statistics. [Online] Available: http://nbs. rs/internet/english/80/index.html\#mon [Accessed: 6 June 2017].

34. National Bank of Serbia Quarter and Annual Report. (n.d.) [Online] Available: http://nbs.rs/ internet/english/55/55_4/index.html [Accessed: 15 July 2017].

35. Nurboja, B and Košak, M. (2017) Banking efficiency in South East Europe: Evidence for financial crises and the gap between new EU members and candidate countries. Economic Systems. [Online] Vol.41(1), pp.122-138. Available: ScienceDirect. [Accessed: 25 July 2017].

36. Roaf, J., Atoyan, R., Joshi, B. and Krogulski, K. (2014) 25 Years of Transition Post-Communist Europe and the IMF. [Online] Available: http://www.imf.org/external/region/bal/rr/2014/25_ years_of_transition.pdf [Accessed 27 May 2017].

37. Sanfey, P. (2010) South-eastern Europe: lessons from the global economic crisis. [Online] Available: http://www.ebrd.com/downloads/research/economics/workingpapers/wp0113.pdf [Accessed: 15 May 2017].

38. Schinasi, G. J. (2004) Defining Financial Stability. [Online] Available: https://www.imf.org/ 
external/pubs/ft/wp/2004/wp04187.pdf [Access: 26 July 2017].

39. Schoenmaker, D. and Werkhoven, D. (2012) What is the Appropriate Size of the Banking System? [Online] Available: http://www.dsf.nl/wp-content/uploads/2014/10/DSF-Policy-Paper-No-28What-is-the-Appropriate-Size-of-the-Banking-System.pdf [Accessed 5 August 2017].

40. The World Bank Data (2017a) Bank nonperforming loans to total gross loans (\%) Serbia. [Online] Available: http://data.worldbank.org/indicator/FB.AST.NPER.ZS?locations=RS [Accessed: 1 June 2017].

41. The World Bank Data (2017b) Bank nonperforming loans to total gross loans (\%) Montenegro. [Online] Available: http://data.worldbank.org/indicator/FB.AST.NPER.ZS?locations=ME [Accessed: 2 June 2017].

42. Van Greuning, H. and Brajovic-Bratanovic, S. (2009) Analysing Banking Risk: A Framework for Assessing Corporate Governance and Risk Management. [Online] Available: https:// openknowledge.worldbank.org/handle/10986/2618 [Accessed: 8 August 2017].

43. Van Horne, J. C. and Wachowicz, J. M. (2008) Fundamental of financial management. 13th ed. Harlow: Pearson Education.

44. Wiesiołek, P. and Tymoczko, D. (2015) The evolution of banking sectors in Central and Eastern Europe - the case of Poland. [Online] Available: http://www.bis.org/publ/bppdf/bispap83.htm [Accessed: 18 June 2017].

45. Živko, I. and Kandžija, T. (2013) Impact of financial crisis on banking sector stability in Republic Croatia. [Online] Available: http://hrcak.srce.hr/106143 [Accessed: 13 May 2017].

46. Živković, B. (2011) Comparative analysis of banking system in Serbia and countries of South-east Europe (Komparativna analiza bankarskog sistema Srbije i zemalja Jugoistočne Evrope). [Online] Available: https://www.fren.org.rs/sites/default/files/qm/L1.pdf [Accessed: 17 May 2017]. 